PROCEEDINGS OF THE WORLD CONFERENCE ON OZONE THERAPY IN MEDICINE, DENTISTRY AND VETERINARY. ANCONA (ITALY). SEPTEMBER 22nd - 23rd - 24th, 2017

\title{
Hyperbaric ozone therapy: scientific considerations [abstract]
}

\section{Robert Jay Rowen}

Private Medical Practice. Santa Rosa, California, United States of America

\section{ABSTRACT}

\section{○ OPEN ACCESS}

\section{Citation}

Rowen RJ. Hyperbaric ozone therapy: scientific considerations [abstract]. Proceedings of The World Conference on Ozone Therapy in Medicine, Dentistry and Veterinary. Ancona (Italy). September 22nd - 23rd - 24th , 2017. J Ozone Ther. 2019;3(4):54. doi: 10.7203/jo3t.3.4.2019.15534

\section{Academic Editor}

Jose Baeza-Noci,

School of Medicine, Valencia

University, SPAIN

\section{Editor}

World Federation of Ozone Therapy,

Bolgna, ITALY

\section{Received}

June 17, 2019

\section{Accepted}

December 08, 2019

Published

December 30, 2019

Intellectual Property

Robert Jay Rowen.

This is an open access article

distributed under the terms of the

Creative Commons Attribution License

(CC BY 4.0), which permits

unrestricted use, distribution, and reproduction in any medium, provided the original author and source are credited.

\section{Author Information} docrowen@gmail.com
Background. This ozone world is little familiar with a modification of major autohemotherapy called hyperbaric ozone therapy $\left(\mathrm{HBO}_{3}\right)$. This method may be a superior delivery system of ozone therapy, capturing benefits of intravenous oxygen gas as well as the oxidizing power of ozone therapy.

Material and Methods. I will discuss a scientific comparison between the largely reviled direct intravenous ozone administration and $\mathrm{HBO}_{3}$, inclusive of a safety/efficacy survey of practicing $\mathrm{HBO}_{3}$ physicians in America.

\section{References}

1. Schmidt, H. [Regelsberger's intravenous oxygen therapy-an interpretation of results in practice from a biochemical and physiological point of view]. Forsch Komplementarmed Klass Naturheilkd. 2002;9(1):7-18 